DOI: $h$ ttps://doi.org/10.31933/dijemss.v3i1 Received: 15 September 2021, Revised: 25 Oktober 2021, Publish: 30 November 2021

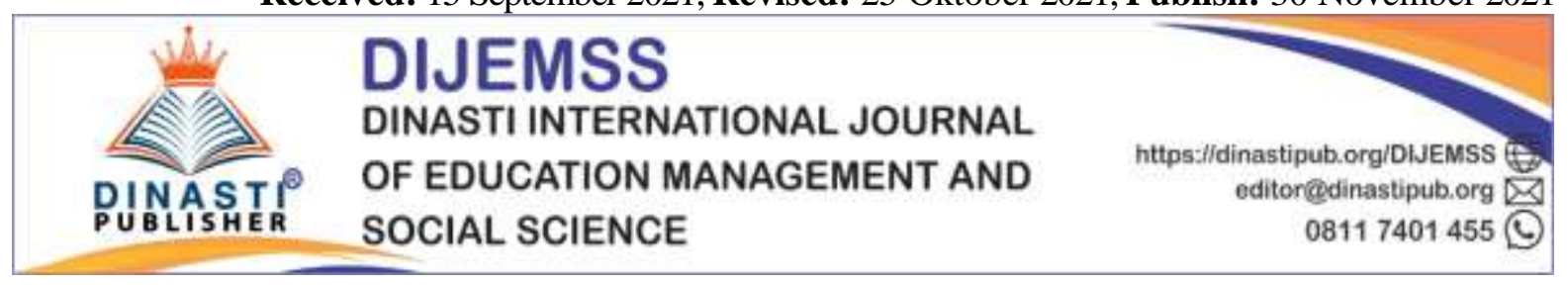

\title{
BUSINESS MODEL CANVAS (BMC): RODA LAMBUNG, DISCOVERING JAMBI MALAY HERITAGE
}

\author{
Anaseputri Jamira ${ }^{1}$, Fachruddin Razi ${ }^{2}$, Muhammad Amali ${ }^{3}$, Yulita Febriani ${ }^{4}$ \\ 1) University of Batanghari, Jambi, Indonesia, anaseputri.jamira@unbari.ac.id \\ 2) University of Batanghari, Jambi, Indonesia, fachruddin.razi@unbari.ac.id \\ 3) University of Batanghari, Jambi, Indonesia, muhammad.amali8702@gmail.com \\ 4) University of Batanghari, Jambi, Indonesia, yulitafebriani585@gmail.com
}

Corresponding author: Anaseputri Jamira

\begin{abstract}
This research is a development of previous research which aims to test the consistency of the Business Model Canvas (BMC) and its application to encourage the entrepreneurial mindset of students in a wider scope, which includes fields not related to economics. Action Research is still used as an approach that is considered appropriate to improve work situations or learning conditions effectively and efficiently. Technical descriptive statistical analysis by comparing the average entrepreneurial mindset of students before and after the application of the BMC method was used, and involved respondents from 13 multidisciplinary fields. The BMC technique in solving cases is also described in more detail in this study. BMC can actually produce unique and mature ideas and even make a big contribution in bringing back the lost historical icon of Jambi, Roda Lambung and presenting it as a historical and tourism product of high value.
\end{abstract}

Keywords: Business Model Canvas, Roda Lambung, Jambi Malay Heritage

\section{INTRODUCTION}

Entrepreneurship is a mindset, skillset and toolset to create the right solution for the surrounding community. There are so many definitions of entrepreneurship but in general entrepreneurship can be defined as the process of identifying, developing and bringing a vision to life. Simply put, entrepreneurship is the process of creating jobs for oneself. The meaning of entrepreneurship is not limited to business, because business does not always provide positive change for others. Therefore, giving benefits to others is the emphasis in entrepreneurship, not just a matter of profit and loss.

Understanding the meaning can be seen from individual behavior such as the way he sees the problem, makes decisions, and solves the problem. So, it is not surprising to say that entrepreneurship in a broader context can strengthen the economic structure of a country through its contribution to economic development, empowerment and improvement of the quality of resources, job creation, and realizing the creation of equitable economic and social welfare. 
Indonesia itself still lacks many entrepreneurs when compared to other developed countries. In fact, Indonesian people consider entrepreneurship as an attractive career choice. The factor in the decline in the desire to become an entrepreneur is because people do not understand the meaning of entrepreneurship which is not only a matter of profit and loss. To overcome this, the government continues to strive to increase the number of entrepreneurs by inserting an understanding of entrepreneurship into the university curriculum. It has even become one of the indicators for ranking universities. (Kemenristekdikti, LLDIKTI Wil. X, 2019).

One of the basic methods of designing business ideas and proposals is the Business Model Canvas (BMC) method. This method is a business model analysis tool with a simple but comprehensive presentation of data on the nine essential components of a business. This method is so popular and widely used in various research case studies (Hermawan, 2020; Indah, 2020; Kamaluddin, 2020; Agusty, 2020; Nurhayat, 2020; Ojasalo and Ojasalo, 2018; Ruspriono, 2020; Siburian, 2020; Tirtayasa, 2020; Victor, 2020). Generally, BMC is used to analyze existing businesses. Whereas BMC is able to encourage the creation of new business ideas or products (Annas, etc, 2021; Candraningrat, etc, 2021; Endratno, etc 2021; Hambali, and Andarini, 2021; Hendarsih, 2021; Tesavritra, 2021; Sukarno, 2021).

Although simple, BMC can help in the early stages of validating a business idea at the planning stage so that it is more mature and ready to run. The mature business idea is reexecuted into a ready-to-use business plan. The BMC method is often introduced and taught in trainings held by LLDIKTI Region X such as the 2021 Student Business Incubation Training. This research is a development of previous research which aims to test the consistency of the Business Model Canvas (BMC) and its application to encourage the entrepreneurial mindset of students in a wider scope, which includes 11 multidisciplinary fields not related to economics, such as law, math, agricultural, agrotechnology, linguistics, history science, etc. This is what underlies the implementation of Research on the Application of the Business Model Canvas to encourage the entrepreneurial mindset among students, Batanghari University in 2021. This is driven by the idea that students' interest in entrepreneurship is still low, one of which is marked by the low level of student participation in the entrepreneurship competition for Batanghari University students who have studied entrepreneurship courses. Therefore, the problem studied in this study is how to apply BMC to encourage the entrepreneurial mindset among Batanghari University students in 2021.

\section{LITERATURE REVIEW}

The business model canvas is depicted through nine basic building blocks that show the logic of how a company intends to make money. These nine blocks cover four key areas of business namely customer, supply, infrastructure and financial viability. In a book entitled "The Startup Owner's Manual: The Step-by-Step Guide for Building a Great Company" written by Steve Blank and Bob Dorf (2012), the nine elements in the business model canvas (customer segment, value propositions, channels, customer relationships, revenue streams, key resources, key activities, key partners, and cost structure). 
Customer segment, the organization must first determine who to serve. The organization may designate to serve one or more segments. Value propositions are the benefits or values the company offers to the market segments it serves. This value offering is also the reason why customers should buy the products/services offered. Channels are channels for connecting with customers which are a means for companies to convey the Value Proposition to the Customer Segments they serve.Customer relationships are the ways in which companies establish good relationships with their customers. Revenue streams are income that is usually measured in terms of money that a company receives from its customers. Key resources are the main resources that a company must have to run a business, in the form of human resources, technology, financial, and physical resources. Key activities are the main activities that must be mastered by the company to run the business.

Key partners are resources needed by the company to realize the value proposition, but are not owned by the company. Cost Structure explains the cost structures involved in the business, both fixed and variable costs. Adi W. Gunawan (2008) in his book The Secret of Mindset, explains that mindset consists of two words, namely Mind and Set. Mind means thinking, or commonly referred to as a source of awareness that can generate thoughts, ideas, feelings and perceptions, and can store memories and knowledge. Set is a complete state or prioritizing increasing ability in an activity. Mindset is a set of beliefs and ways of thinking that can determine a person's views, behavior, attitudes and future. According to Ita Athia, Ety Saraswati, and Andi Normaladewi (2018) that the Entrepreneurial Mindset can be seen from 5 factors, namely how much interest in entrepreneurship, knowledge possessed about business components, knowledge about how to start a business, courage to create a business, and ability to be creative and innovate.

\section{RESEARCH METHODS}

This research is qualitative and quantitative. Both analyzes were used simultaneously (Prof. Sugiono, 2006). At the initial stage, a survey was conducted to determine the initial condition of the entrepreneurial mindset of Economics students at Batanghari University, using a questionnaire instrument to determine how much students are interested in entrepreneurship, knowledge of business components and how to start a business, courage to create a business, and ability to be creative and innovate. Previous research by Ita Athia, Ety Saraswati, and Andi Normaladewi (2018) used a library research method which studied interesting topics or was traditional research whose research results were limited to theory development. This is deemed inappropriate, considering that the research focuses on the aspects of its application. The existence of a gap from previous research is the background for the use of the Action Research Method. The Action Research Method, also known as Participatory Research, Collaborative Inquiry, Emancipatory Research, Action Learning, and Contextual Action Research, according to Sugiyono (2015), is a research approach with two (dual) goals, namely taking new actions. effective and efficient way to improve work situations (take action) and to develop science/knowledge or theory of action (science of action). If the traditional research is only one, it focuses on theory development. 
Action research is practical research. So the chosen action has been proven through research. Action research is used to find knowledge about how to make improvements. There are four levels/designs in action research. Level 1 action research, is action research where the researcher conducts research to find out the potential and problems, and then the researcher gives suggestions for action, but does not test the action. Level 2 action research, is action research where researchers do not conduct research to find out potential and problems (only reflect), but directly test action plans that are believed to be able to solve problems or improve performance. Level 3 action research, is action research where researchers conduct research to find problems and potentials, and then researchers develop existing actions and test these actions. Level 4 action research, is action research where researchers conduct research to find problems and potentials, and then researchers find or create new actions and test these actions. From a scientific and methodological perspective, the highest level of action research is Level 4 action research. The research conducted by the researcher is Level 3 Action Research, where the researcher conducts research to find problems and potentials, and then the researcher develops existing actions and tests these actions with the BMC method/theory.

The sample involved 100 students from 13 multidisciplinary fields using the quota sampling method, which is a non-probability sampling technique. Where this technique determines a sample from the population that has the characteristics of the provisions until the desired amount (quota) (Sugiyono, 2019). The reason this sampling technique was chosen was to meet strict health protocol standards in the face of Covid-19. The next stage was the introduction of the application of BMC in the classroom and assigned to plan a business idea, for three meetings, two face-to-face sessions, and one video conference session. Data collection techniques with observation and documentation.

The research instrument used in the form of an entrepreneurial mindset assessment questionnaire filled out by students using a Likert scale with levels 1-4 on five aspects of the entrepreneurial mindset, namely how much interest in entrepreneurship, knowledge possessed about business components, knowledge about how to start a business, courage to create business, and the ability to be creative and innovate. Where the meaning of the number $4=\operatorname{Very} \operatorname{High}(\mathrm{ST}), 3=\operatorname{High}(\mathrm{T}), 2=\operatorname{Enough}(\mathrm{C})$, and $1=$ Low $(\mathrm{R})$.

\section{FINDINGS AND DISCUSSION}

Before giving the BMC material, at the initial stage a survey was conducted to determine the condition of the initial entrepreneurial mindset of 100 samples. Table 1 shows that the entrepreneurial mindset of students before the application of the BMC Method was 48 people $(48 \%)$ in the low category, 15 people $(15 \%)$ in the moderate category, 30 people $(30 \%)$ in the high category, and 7 people $(7 \%)$ is included in the very high category. It appears that most of the students' entrepreneurial mindsets are still in the low category. 
Table 1. Observation of Student Entrepreneurship Mindset Before Giving BMC Material

\begin{tabular}{cccc}
\hline No. & Description & Frequency & Percentage (\%) \\
\hline 1 & Very High & 7 & 7 \\
2 & Tall & 30 & 30 \\
3 & Enough & 15 & 15 \\
4 & Low & 48 & 48 \\
& Total & $\mathbf{1 0 0}$ & $\mathbf{1 0 0}$ \\
\hline
\end{tabular}

Source: Researcher Data Process

At the stage of providing BMC material, the BMC process is explained by providing examples of real simulations in practice using them to generate business ideas. At this stage, it explains the steps, starting from generating ideas, doing designs, testing stages, pivoting processes, and finally telling about experiences. How to come up with ideas, ideas can come from problems. So the thing that was done was to have discussions with several Jambi community members both directly and via the internet and observations were made to find problems that existed in the surrounding environment.

There were several problems obtained, namely the lack of tourist and entertainment destinations in Jambi City, the lack of interest of the Jambi City community towards Jambi arts and culture, the Jambi community's lack of concern for nature conservation in Jambi, such as the Batanghari River and Sipin Lake, and the absence of a place for discussion/ learning/sharing knowledge and information that can be accessed 24 hours in Jambi.

Based on the assumption, the solution offered is a cruise ship (an international, complete, luxurious and exclusive tourist destination that sails on the Batanghari River). Design with the initial idea of a cruise ship with the concept of Jambi Malay culture nuanced (as the oldest Malay in the world); dominated by gold; Malay cultural performances; city center and shopping in Jambi Malay nuanced cruise, convention center, sport center, beauty center, learning center, etc.; sailing ships and stopping at tourist villages along the Batanghari River, the historic site of Muaro Jambi Temple, Berhala Island, to Malacca; as the most complete Jambi and national hawker and culinary center and offers world cuisine. A real picture of the explanation with the Cruise Ship Initial BMC method is clearly presented on the screen which describes all 9 BMC components related to the Cruise Ship Idea.

After designing the BMC "cruise ship", testing was carried out. The test is carried out by having a conversation with the Expert and asking for input; conducting surveys to the Port, Shipping Line, Aur Duri Bridge I and Aur Duri Bridge II; conduct direct interviews with several potential customers; held discussions with several Jambi residents; look for supporting secondary data; and the last one did a small survey through Social Media. After field surveys such as visiting the Talang Duku port in Jambi province, which is located not 
far from the city center, the Cruise Lines are the Batanghari River, Aur Duri Bridge I and Aur Duri II Bridge. An overview of one of Jambi's iconic mega projects is obtained, namely the Gentala Arasy Tower and the Suspension Bridge.

This Suspension Bridge was built right in front of the Jambi Governor's Office House which will connect with the Jambi City Seberang area. Furthermore, discussions were held with the residents of Jambi, namely Nasir and Heri, who are members of the Jambi Arts Team. They responded that the concept was good, but why not take the Ferris wheel from Jambi as the shape of the ship. Several facts were also found, namely the location of Talang Duku Jambi Port, which is $\pm 10 \mathrm{~km}$ from the City Center; Talang Duku Port can only be visited by small ships; the location of the ship's dock which is also in the Talang Duku area; the condition of the Batanghari River Cruise Line is experiencing sedimentation (silting), especially the upstream flow; accelerated international port development by the Government in Sabak which is strategically located, directly opposite the Malacca Strait and the Triangle of Growth Centers (Singapore, Malaysia and Batam.

Other facts found are cruise ships with a minimum weight of 1000 tons; cruise ships can sail at a minimum depth of 12 meters; The Batanghari River on average reaches a depth of 8-10 meters; at high tide it can reach 12 meters while at low tide it only reaches 3.8 meters; the maximum weight of ships sailing on the Batanghari river is a maximum of 500 tons; the dredging program for the depth of the Batanghari river carried out by the government has not been realized in the near future. The next step is Pivot, based on the facts found from the results of field observations, discussions, interviews and the acquisition of secondary data, it can be concluded that the cruise ship tourist destination has not been realized. However, it does not rule out the possibility of water tourism destinations in other forms. So the idea was raised to create a Floating Restaurant that elevates the nuances of the Jambi Traditional Ship, which is Roda Lambung.

After giving the BMC material, it can be seen that based on Table 2, the number of students who have a high and very high entrepreneurial mindset is $60 \%$, more than students who have a fairly low and low entrepreneurial mindset, which is $40 \%$.

Table 2. Observation of Student Entrepreneurship Mindset After Giving BMC Material

\begin{tabular}{cccc}
\hline No. & Description & Frequency & Percentage (\%) \\
\hline 1 & Very High & 24 & 24 \\
2 & Tall & 36 & 36 \\
3 & Enough & 35 & 35 \\
4 & Low & 5 & 5 \\
& Total & $\mathbf{1 0 0}$ & $\mathbf{1 0 0}$ \\
\hline
\end{tabular}

Source: Researcher Data Process 
Before the application of the BMC Method, the percentage of students who had a high entrepreneurial mindset was only 37 people or $37 \%$. Then, after the application of the BMC Method, the percentage of students who have a high entrepreneurial mindset increased to 60 people or $60 \%$. The scope of this research is wider than previous research, which is increased to the level of Higher Education (Jamira, et al, 2021).

\section{CONCLUSION AND SUGGESTION}

The results showed that the BMC method could increase the Entrepreneurial Mindset of Batanghari University Students. Students have a good understanding of the knowledge of how to start a business, and have the courage, ability to be creative, and innovate as well as a high interest in starting a business. The researcher found that there were several other main potential problems that drive the Student Entrepreneurship Mindset, namely first, generally students have not understood or found their passion in life that underlies the desire to be an entrepreneur. Second, students do not understand the true meaning of entrepreneurship, which is not only a matter of profession but is a soul that should be owned by every individual. Third, the absence of a Support System that helps support the execution of Business Plan until they are realized and run successfully as expected. The BMC method deserves to be introduced and taught to students in Entrepreneurship Courses. Students need to receive Training on Self-Development and SWOT Analysis to explore Passion in order to build a Life Vision and Mission that influences the direction of Entrepreneurship. Students need to receive training on understanding the true essence of entrepreneurship, which is not just a "profession" but a "soul" that must be possessed by every individual who helps to form a tough and multitalented character in facing the Revolutionary Era and uncertainty as it is today. The need to build a Support System in Jambi City that is easily accessible by students.

\section{BIBLIOGRAPHY}

Agusty, Rosana Mia. 2020. Designing Business Model Canvas Transforms Into Balanced Scorecard in the XYZ University in Indonesia. Dinasti International Journal of $\begin{array}{lllll}\text { Management } \quad \text { Science. } & 1, & 6 & \text { (Jul. 2020), }\end{array}$ https://doi.org/10.31933/dijms.v1i6.392

Annas, Azwar, Taher Jufri, Muhammad, dan Jusmawati, Jusmawati. 2021. Penerapan Business Model Canvas pada E-Commerce Toko H5 Jayapura. JSAI : Journal Scientific and Applied Informatics, Vol. 4, No. 2, hal. 204-220, E-ISSN; 2614-3054, P-ISSN: 2614-3062. http//:jurnal.umb.ac.id/index.php/JSAI/article/view/1671

Athia, Ita, Saraswati, Ety, and Normaladewi, Andi. 2018. Penerapan Business Model Canvas (BMC) untuk Mendorong Mindset Kewirausahaan di Kalangan Mahasiswa Universitas Islam Malang. Jurnal Ketahanan Pangan, 2(1), 66-75. http://riset.unisma.ac.id/index.php/JU-ke/article/view/1051/1086

Blank, Steve, and Dorf, Bob. 2012. The Startup Owner's Manual: The Step-by-Step Guide for Building a Great Company. United State of America: K\&S Ranch.

Candraningrat, Yuan Yurisma, Dhika, dan Siti Mujanah. 2021. Pengembangan Strategi Bisnis Melalui BMC (Business Model Canvas) Dan Strategi Pemasaran Bagi Umkm Sari Delight Surabaya. TEKMULOGI: Jurnal Pengabdian Masyarakat. Vol. 1, No. 1 
(2021), pp. 16-24 . https://ejournal.upi.edu/index.php/Tekmulogi/article/view/34295

Ching, Hong Y., and Fauvel, Clemens. 2013. Criticisms, Variations and Experiences with Business Model Canvas. European Journal of Agriculture and Forestry Research, 1(2), 26-37. http://www.eajournals.org/wp-content/uploads/Criticisms-Variations-andExperiences-with-Business-Model-Canvas.pdf

Endratno, Hermin, Rusman, Ade, dan Hidayah, Arini. 2021. Model Bisnis Canvas Hutan Pinus Limpakuwus Purwokerto. Derivatif : Jurnal Manajemen, Vol. 15 No. 1 April 2021, ISSN Cetak 1978-6573, ISSN Online 2477-300X. https://fe.ummetro.ac.id

Gunawan, Adi W. 2008. The Secret of Mindset. Jakarta: Gramedia Pustaka Utama.

Hambali, Achmad, dan Andarini, Sonja. 2021. Formulasi Strategi Pengembangan Bisnis Menggunakan Pendekatan Business Model Canvas (BMC) dan Swot Analysis Dalam Upaya Meningkatkan Daya Saing Pada Piring Seng Coffee \& Co Tunjungan Surabaya. Journal of Applied Business Administration (JABA), ISSN 2548-9909. http://journal.uny.ac.id.

Hendarsih, Ida. 2021. Analisis Penerapan Strategi Business Model Canvas (BMC) Pada Jasa Zigzag Laserwork Semarang Jawa Tengah. Jurnal Akrab Juara, Volume 6 Nomor 4 Edisi November $2021 \quad$ p. 152-167, ISSN 2620-9861. https://akrabjuara.com/index.php/akrabjuara/article/view/1599

Hermawan, Frendy. 2020. Analysis of Family Business Development Model Based on Business Model Canvas (Case Study in CV. MXY). Dinasti International Journal of Digital Business $\quad$ Management, $\quad 1(5), \quad 829-841$. https://dinastipub.org/DIJDBM/article/view/486

Indah, RA. Iis Suci Nur. 2020. Planning Business Model Canvas with SWOT Method at XYZ Institute. Dinasti International Journal of Digital Business Management, 1(5) 781-793. https://dinastipub.org/DIJDBM/article/view/483

Jamira, Anaseputri, Amali, Muhammad dan Febriani, Yulita. 2021. Business Model Canvas (BMC): Sebuah Pendekatan dalam Mendorong Mindset Kewirausahaan. Prosiding Seminar Nasional dan Call for Paper 2020 Fakultas Ekonomi dan Bisnis Universitas Muhammadiyah Jember "Sinergitas Kampus dan Pelaku Bisnis dalam Recovery Pertumbuhan Ekonomi Nasional”, yang dipresentasikan pada 30 Januari 2021. UM Jember Press. http://jurnal.unmuhjember.ac.id/index.php/PSNCFEB/index

Jamira, Anaseputri, Agustiningsih, Nur, and Febriani, Yulita. 2021. The Implementation of Business Model Canvas (BMC) to Improve Students' Entrepreneurship Mindset. Dinasti International Journal of Education Management and Social Science (DIJMSS), 2(3), 395-403. https://dinastipub.org/DIJEMSS/article/view/751/469

Kamaluddin, Iqbal. 2020. Business Development Strategy with Canvas Model Business Approach in CV. Hakhenbik. Dinasti International Journal of Economic, Finance, and Accounting, 1(3), 469-481. https://doi.org/10.38035/dijefa.v1i3.431

Kemenristekdikti, LLDIKTI Wil. X. 2019. Panduan Entrepreneurship Award III-2019. Unpublished. Padang: LLDIKTI Wil. X.

McGrath, Rita Gunther, and MacMillan, Ian. 2000. The Entrepreneurial Mindset: Strategies for Continuously Creating Opportunity in an Age of Uncertainty. Boston, Massachusetts: Harvard Business School Press.

Nurhayat, Kartika. 2020. Designing Business Canvas Model and Analysis Business in 
Warung Dimsum. Dinasti International Journal of Management Science, 1(6), 903912. https://doi.org/10.31933/dijms.v1i6.398

Ojasalo, Jukka, and Ojasalo, Katri. 2018. Service Logic Business Model Canvas. Journal of Research in Marketing and Entrepreneurship: Emerald Publishing Limited, 20(1), 1471-5201.

https://www.researchgate.net/publication/338300234_Service_Logic_Business_Model _Canvas_for_Lean_Development_of_SMEs_and_Start-Ups

Osterwalder, Alexander, and Pigneur, Yves. 2010. Business Model Generation: A Handbook for Visionaries, Game Changers, and Challengers. Hoboken, New Jersey: John Wiley \& Sons, Inc. https://www.academia.edu/18868178/Business_Model_Generation_A_Handbook_for _Visionaries_Game_Changers_and_Challengers

Ruspriono. 2020. Business Analysis Model Using Canvas Business Model Approach to KJPP Yanuar Bey and Partners. Dinasti International Journal of Digital Business Management, 1(4) 608-617. https://dinastipub.org/DIJDBM/article/view/370

Siburian, Agus Mangiring. 2020. Implementation of Business Model Canvas in Chemical Manufacturing Company PT. Timuraya Tunggal. Dinasti International Journal of Economic, Finance, and Accounting, 1(3), 421-430. https://dinastipub.org/DIJEFA/article/view/421

Sugiyono. 2006. Metode Penelitian Pendidikan (Pendekatan Kuantitatif, Kualitatif, dan R \& D). Bandung: Alfabeta.

Sugiyono. 2015. Metode Penelitian Tindakan Komprehensif. Bandung: Alfabeta.

Sugiyono. 2019. Metode Penelitian Pendidikan. Bandung: Alfabeta.

Sukarno, Bangkit Rambu, dan Ahsan, Muhammad. 2021. Implementasi Strategi Pengembangan Bisnis Dengan Business Model Canvas. Jurnal Manajemen dan Inovasi (MANOVA), Volume IV Nomor 2, P ISSN: 2685-4716, E ISSN: 2746-282X. http://jurnalfebi.uinsby.ac.id/index.php/MANOVA/article/view/456

Tesavritra, Ceicalia. 2021. Pengembangan Model Bisnis UKM Batik X Dengan Menggunakan Business Model Canvas (BMC). MANNERS, Vol .IV, No. 1, Maret 2021. https://jurnal.unnur.ac.id

Tirtayasa, Yohan. 2020. Canvas Business Strategy in the Aapplication of Local Credits in Bank BCA. Dinasti International Journal of Management Science, 1(6), 854-862. https://doi.org/10.31933/dijms.v1i6.394

Victor. 2020. Business Analysis of Canvas and SWOT Models (Case Study for Culinary Crossbreed Cake "Tn. Xyz"). Dinasti International Journal of Economic, Finance, and Accounting, 1(3), 515-525. https://dinastipub.org/DIJEFA/article/view/451 